\title{
Characterization of a chemostable serine alkaline protease from Periplaneta americana
}

Prashant T Sanatan ${ }^{1 \dagger}$, Purushottam R Lomate ${ }^{1,2+}$, Ashok P Giri ${ }^{2}$ and Vandana K Hivrale ${ }^{1 *}$

\begin{abstract}
Background: Proteases are important enzymes involved in numerous essential physiological processes and hold a strong potential for industrial applications. The proteolytic activity of insects' gut is endowed by many isoforms with diverse properties and specificities. Thus, insect proteases can act as a tool in industrial processes.

Results: In the present study, purification and properties of a serine alkaline protease from Periplaneta americana and its potential application as an additive in various bio-formulations are reported. The enzyme was purified near to homogeneity by using acetone precipitation and Sephadex G-100 gel filtration chromatography. Enzyme activity was increased up to 4.2 fold after gel filtration chromatography. The purified enzyme appeared as single protein-band with a molecular mass of $\sim 27.8 \mathrm{kDa}$ in SDS-PAGE. The optimum pH and temperature for the proteolytic activity for purified protein were found around $\mathrm{pH} 8.0$ and $60^{\circ} \mathrm{C}$ respectively. Complete inhibition of the purified enzyme by phenylmethylsulfonyl fluoride confirmed that the protease was of serine-type. The purified enzyme revealed high stability and compatibility towards detergents, oxidizing, reducing, and bleaching agents. In addition, enzyme also showed stability towards organic solvents and commercial detergents.

Conclusion: Several important properties of a serine protease from $P$. Americana were revealed. Moreover, insects can serve as excellent and alternative source of industrially important proteases with unique properties, which can be utilized as additives in detergents, stain removers and other bio-formulations. Properties of the P. americana protease accounted in the present investigation can be exploited further in various industrial processes. As an industrial prospective, identification of enzymes with varying essential properties from different insect species might be good approach and bioresource.
\end{abstract}

Keywords: Periplaneta americana, Serine alkaline protease, Chemostability, Insect proteases, Industrial catalyst

\section{Background}

Proteases catalyze the hydrolysis of proteins, which leads to the production of small peptides and amino acids [1]. The vast diversity in proteases, regardless of their mode of action and specificity has attracted worldwide attention for using them in biotechnological applications [2]. Recent years have witnessed a significant increase in the use of enzymes as industrial catalysts. The global market for industrial enzymes was estimated around $\$ 3.3$ billion in 2010. This market is expected to reach $\$ 4.4$ billion by 2015 , with the annual growth rate of $6 \%$ over the 5 -year forecast period [1]. Proteases represent one of the major

\footnotetext{
* Correspondence: vkhbiochem@gmail.com

${ }^{\dagger}$ Equal contributors

'Department of Biochemistry, Dr. Babasaheb Ambedkar Marathwada University, Aurangabad 431004, MS, India

Full list of author information is available at the end of the article
}

groups of enzymes produced and account for $60 \%$ of the worldwide sale of the total industrial enzymes [2]. Alkaline proteases hold a big share of the enzyme market and primarily used as detergent additives. Furthermore, alkaline proteases are found to be useful in other industrial sectors, such as leather, food, feed, textile, organic synthesis, pharmaceutical, silk, and for recovery of silver from used X-ray films [3-5]. Although bacterial and fungal [6-8], proteases are used in various industrial applications, insect proteases have comparatively gained lesser attention.

Microorganisms, such as bacteria and fungi remain a major source to obtain industrially important protease till date. In fact, most of the alkaline proteases are especially derived and extensively studied from high yielding strains of Bacillus species [5,8]. However, most of the alkaline proteases from microbial species applied for industrial purpose have some limitations, which include low activity 
and stability towards anionic surfactant (Sodium dodecyl sulphate SDS) and oxidizing agents (bleach and $\mathrm{H}_{2} \mathrm{O}_{2}$ ) that are common ingredients in modern detergent formulations. And secondly production cost; around 30 to $40 \%$ of the production cost of industrial enzymes is accounted for the growth medium of proteases [9]. The industrial demand of highly active preparations of proteolytic enzymes with appropriate specificity and chemostability eventually stimulated the search of alternative protease source.

In this context, insects can act as a promising option for isolating proteases that hold industrially important characteristics. The digestive enzymes of the insects are of interest as a target for insect control and also because of their unusual ability to function in alkaline microenvironment of the gut (pH 10.0 to 12.0) [10]. These observations substantiate that insect gut proteases are finely designed to work optimally in alkaline conditions [11]. Proteolysis is an essential part of food digestion in insects and this process is mediated by the concerted action of several digestive enzymes, which possess the important characteristics such as high temperature and alkaline $\mathrm{pH}$ optimum [12,13]. Therefore, these characters of insect proteases are promising while using them for industrial purpose [14]. Previously, we showed that crude gut extract of $P$. americana contains several trypsin and chymotrypsin-like proteases [15]. These enzymes were found to be highly active at alkaline $\mathrm{pH}$ therefore could be used as detergent additives. The proteases from $P$. americana and other insect species exhibit highly alkaline optimum $\mathrm{pH}$ ranging from 10 to 12. Thus, investigating the potential of $P$. americana gut proteases is of great importance as an industrial point of view. We have selected $P$. americana midgut caecae as a source of study, since it is a factory of diverse proteases, with an objective to exploit properties of these important enzymes.

Here, we report the isolation, purification and characterization of a serine alkaline protease from $P$. americana midgut caecae. The isolated enzyme exhibited stability towards anionic, nonionic surfactants, oxidizing agents and organic solvents. Furthermore, the potential applications of the purified protease in various industries have been discussed.

\section{Methods}

Material

The following chemicals were obtained from SigmaAldrich, St. Louis, MO, (USA): Casein, Sephadex G-100, bovine serum albumin (BSA), phenylmethylsulfonyl fluoride (PMSF), ethylene diamine tetra acetate (EDTA), 5, 5Dithiobis (2-nitrobenzoic acid) (DTNB) and $\beta$-mercaptoethanol. Heavy metal ions, surfactants, organic solvents and chemicals for electrophoresis were purchased from Merck, Germany. Gel X-ray films and medium range molecular mass markers (14.3 to $97.4 \mathrm{kDa})$ were obtained from Selvas photographic Ltd. Silvassa, India and Genei, Bangalore, India respectively. Commercial detergent powders such as Ariel, Tide, Surf, Ghadi, Henko and Rin were purchased from local market. All other chemicals used were of high analytical grade. Periplaneta americana insects were collected from grain godowns in Aurangabad, Maharashtra state India.

\section{Preparation of enzyme extract}

Insects were immobilized by keeping at $-20^{\circ} \mathrm{C}$ for $2 \mathrm{~h}$ and dissected mid-ventrally. Midgut caecae were removed and homogenized with pre-chilled mortar and pestle in 1:6 (w/v) volumes of ice-cold $0.1 \mathrm{M}$ Tris- $\mathrm{HCl}$ buffer $\mathrm{pH}$ 8.0. The homogenate was centrifuged at $10,000 \mathrm{rpm}$ for $20 \mathrm{~min}$ at $4^{\circ} \mathrm{C}$. The supernatant was collected and divided into $2 \mathrm{~mL}$ aliquots and stored at $-20^{\circ} \mathrm{C}$ until use. Protein concentration in the supernatant was measured by Lowry's method using bovine serum albumin as standard [16].

\section{Total proteolytic activity assay}

Total proteolytic activity was determined by caseinolytic assay $[17,18]$. Different protein concentrations from $P$. americana caecae extract were added into $2 \mathrm{~mL}$ of $0.5 \%$ casein (prepared in $0.1 \mathrm{M}$ Tris- $\mathrm{HCl}$ buffer $\mathrm{pH}$ 8.0) and the mixture was incubated for $20 \mathrm{~min}$ at $40^{\circ} \mathrm{C}$. After $20 \mathrm{~min}$ the reaction was terminated by adding $3 \mathrm{~mL}$ of $5 \%$ trichloro acetic acid (TCA). The absorbance of TCA soluble peptides was measured at $280 \mathrm{~nm}$.

\section{Purification steps}

\section{Acetone precipitation}

To the supernatant $(50 \mathrm{~mL})$ equal amount of chilled acetone was added and kept overnight at $-20^{\circ} \mathrm{C}$. Next day the precipitate was collected and centrifuged at 10,000 rpm for $20 \mathrm{~min}$ at $4^{\circ} \mathrm{C}$. Acetone was removed by air drying and the remaining precipitate was collected. The precipitate was dissolved in minimum amount of $0.1 \mathrm{M}$ Tri- $\mathrm{HCl}$ buffer $\mathrm{pH} 8.0$ and centrifuged at 10,000 rpm for $20 \mathrm{~min}$ and the supernatant was collected.

\section{Gel filtration chromatography}

Sephadex G-100 (5 gm) gel was added in 0.1 M Tris- $\mathrm{HCl}$ ( $\mathrm{pH} 8.0)$ and allowed to swell for overnight and column $(1.5 \times 65 \mathrm{~cm})$ was packed. The column $(1.5 \times 65 \mathrm{~cm})$ was equilibrated with $0.1 \mathrm{M}$ Tris- $\mathrm{HCl}$ buffer $\mathrm{pH}$ 8.0. Total $5 \mathrm{~mL}$ of acetone precipitate was loaded onto a Sephadex G-100 column $(1.5 \times 65 \mathrm{~cm})$. The column was eluted with Tris- $\mathrm{HCl}$ buffer ( $\mathrm{pH} 8.0$ ) and fractions of $1 \mathrm{~mL}$ were collected at a flow rate of $1 \mathrm{~mL} / \mathrm{min}$. Protein concentration from each fraction was determined by Lowry method using bovine serum albumin as standard [16]. 


\section{Molecular mass determination}

Molecular mass of the purified enzyme was determined on $12 \%$ sodium dodecyl sulphate polyacrylamide gel electrophoresis (SDS-PAGE) according to the method of Laemmli [19]. Approximately $10 \mu \mathrm{g}$ of purified protein was loaded on $12 \%$ SDS-PAGE with standard molecular mass markers and electrophoresis was carried out at a constant current of $30 \mathrm{~mA}$. After electrophoresis the gel was stained with Coomassie Brilliant Blue R-250 (CBB $\mathrm{R}-250$ ) and destained to visualize protein bands.

\section{Visualization of protease isoforms by gel X-ray film contact print method}

To visualize the activity of proteases in each purification step, the fractions were separated on $10 \%$ native-PAGE and the electrophoresis was carried out at constant current of $20 \mathrm{~mA}$. After PAGE, the gel was equilibrated in $0.1 \mathrm{M}$ Tris- $\mathrm{HCl}$ buffer $\mathrm{pH} 8$ for 10 min followed by placing the gel on fresh X-ray film and incubating at $37^{\circ} \mathrm{C}$ for $30 \mathrm{~min}$ $[15,20]$. The gel was removed and X-ray film was washed with warm water. Protease isoforms in the gel were detected in terms of gelatin hydrolysis of X-ray film, which served as substrate.

\section{Optimum $\mathrm{pH}$ and $\mathrm{pH}$ stability of purified protease}

The activity of purified enzyme in various buffers was evaluated by adding $20 \mu \mathrm{L}$ purified enzyme in pre-incubated buffers $(1 \mathrm{~mL}, 0.1 \mathrm{M})$ of $\mathrm{pH}$ ranging from $\mathrm{pH} 3.0$ to

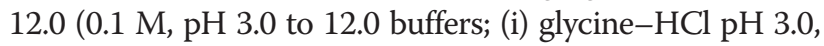
(ii) acetate buffer $\mathrm{pH} 4.0,5.0$, (iii) phosphate buffer $\mathrm{pH}$ 6.0, 7.0, (iv) Tris- $\mathrm{HCl} \mathrm{pH} \mathrm{8.0,} 9.0$ and, (v) glycine- $\mathrm{NaOH}$ $\mathrm{pH} 10.0,11.0$, and 12.0$)$ and $1 \mathrm{~mL}$ of $0.5 \%$ casein dissolved in distilled water. The reaction was carried out at $37^{\circ} \mathrm{C}$ and terminated after $20 \mathrm{~min}$ by adding $3 \mathrm{~mL}$ of $5 \% \mathrm{TCA}$. The absorbance of TCA soluble peptides was measured at $280 \mathrm{~nm}$. For the determination of $\mathrm{pH}$ stability, the purified enzyme was incubated in buffers having different $\mathrm{pH}$ ranging from $\mathrm{pH} 7.0$ to 12.0 for $1 \mathrm{~h}$ at $40^{\circ} \mathrm{C}$ and the enzyme activity was determined under standard assay conditions.

\section{Effect of temperature on activity and stability \\ of the protease}

The activity of purified protease at different temperatures $\left(10-100^{\circ} \mathrm{C}\right)$ was evaluated by adding $20 \mu \mathrm{L}$ purified enzyme in $2 \mathrm{~mL}$ of $0.5 \%$ casein. Reaction mixture and substrate solution were pre-incubated for $30 \mathrm{~min}$ at given temperatures before activity measurement. The assay was carried out as mentioned above at different preset temperatures for $20 \mathrm{~min}$. The temperature stability of the purified enzyme was also checked. To examine the temperature stability, the purified enzyme was incubated at different temperatures ranging from 50 to $70^{\circ} \mathrm{C}$ for $1 \mathrm{~h}$ and the residual enzyme activity was measured under standard assay conditions.
Effects of inhibitors and metal ions on protease activity

The effect of inhibitors on purified protease activity was studied using PMSF (1 mM), EDTA (5 mM), DTNB (5 $\mathrm{mM})$ and $\beta$-mercaptoethanol $(5 \mathrm{mM})$ [21]. The reaction mixture was prepared by pre-incubating the purified enzyme with inhibitors for $10 \mathrm{~min}$ at $40^{\circ} \mathrm{C}$. The protease assay was performed for $30 \mathrm{~min}$ at $40^{\circ} \mathrm{C}$ by above-mentioned method. Protease activity obtained without inhibitor was considered as $100 \%$. Effect of monovalent $\left(\mathrm{Na}^{+}\right.$and $\left.\mathrm{K}^{+}\right)$ and divalent $\left(\mathrm{Cd}^{2+}, \mathrm{Zn}^{2+}, \mathrm{Cu}^{2+}, \mathrm{Ba}^{2+}\right.$ and $\left.\mathrm{Hg}^{2+}\right)$ metal ions on enzyme activity at a concentration of 5, 10 and $15 \mathrm{mM}$ was investigated by using casein as substrate [21]. The reaction mixture was prepared by pre-incubating the purified enzyme with metal ions at each concentration for $10 \mathrm{~min}$ at $40^{\circ} \mathrm{C}$ and the proteolytic activity was determined for $1 \mathrm{~h}$ by above-mentioned method. Enzyme activity without metal ions was considered as $100 \%$.

\section{Effect of surfactants and oxidizing agents}

The suitability of the purified protease as a detergent additive was determined by testing its stability towards surfactants (Tween 20, Tween-80, Triton X-100 and SDS) and oxidizing agents $\left(\mathrm{H}_{2} \mathrm{O}_{2}\right.$ and bleach). The reaction mixture was prepared by pre-incubating the purified enzyme with surfactant and oxidizing agents at each concentration for $10 \mathrm{~min}$ at $40^{\circ} \mathrm{C}$ and protease activity assay was carried out for $1 \mathrm{~h}$ as mentioned above. Enzyme activity without any surfactant and oxidizing agent was considered as $100 \%$.

\section{Effect of organic solvents}

The effect of various organic solvents such as acetone, xylene, benzene, propanol, DMSO, toluene, ethanol, butanol and hexane on purified protease activity was tested. The reaction mixture was prepared by pre-incubating the purified enzyme with each solvent for $10 \mathrm{~min}$ at $40^{\circ} \mathrm{C}$. Reaction mixture was prepared in $0.1 \mathrm{M}$ Tris- $\mathrm{HCl}$ buffer ( $\mathrm{pH}$ 8.0) to get final concentration of each solvent as $25 \%$ and enzyme activity was determined as mentioned for surfactants and oxidizing agents. Enzyme activity without any organic solvent was considered as $100 \%$.

\section{Stability of protease toward commercial detergents}

The stability of purified protease was checked against several commercial detergent powders such as Ariel, Tide, Surf, Wheel, Henko, and Rin. Detergent solutions were prepared in $0.1 \mathrm{M}$ Tris- $\mathrm{HCl}$ buffer ( $\mathrm{pH} 8.0$ ) to get final concentration of 1,10 and $100 \mathrm{mg} / \mathrm{mL}$ of the each detergent. Prior to assay detergent solutions were heated at $100^{\circ} \mathrm{C}$ for $1 \mathrm{~h}$ to deactivate the endogenous proteases present in the commercial detergents. The reaction mixture was prepared by pre-incubating the purified enzyme with each detergent with different concentrations for $10 \mathrm{~min}$ at $40^{\circ} \mathrm{C}$ and protease activity was determined by 
above-mentioned method. The activity of enzyme without detergent was considered as $100 \%$.

\section{Statistical analysis}

All the experiments excluding purification steps were carried out at least three times. Standard deviation and standard error were calculated using MS-Excel.

\section{Results}

\section{Purification and molecular mass determination}

The protease from $P$. americana midgut caecae was purified by using acetone precipitation and gel filtration chromatography. The enzyme was purified up to 4.2 fold with $19 \%$ recovery. The specific activity of the enzyme was increased up to 4.2 fold after gel filtration chromatography. The results of the purification procedure are summarized in Table 1. The purified fraction was loaded on $12 \%$ SDSPAGE and electrophoresis was carried out. The purified enzyme was appeared as single band on 12\% SDS-PAGE when stained with CBBR-250. The molecular mass of the purified enzyme was estimated to be $\sim 27.8 \mathrm{kDa}$ (Figure 1A). The molecular mass of the purified protein was confirmed by the Sephadex G-100 column. The purity of the enzyme was further checked by detecting the protease activity band on X-ray film (Figure 1B).

\section{Optimum $\mathrm{pH}$ and stability of the purified protease}

The effect of $\mathrm{pH}$ on purified protease activity was determined over a $\mathrm{pH}$ range of 3 to 12 . The enzyme was found to be highly active in the $\mathrm{pH}$ ranges from 7 to 12, with an optimum $\mathrm{pH} 8$ (Figure $2 \mathrm{~A}$ ). The $\mathrm{pH}$ stability profile of the enzyme is shown in Figure 2B. The purified enzyme was observed to be stable at a $\mathrm{pH}$ range between 7 and 12 and recovered $90 \%$ of its original activity up to $1 \mathrm{~h}$ incubation at $40^{\circ} \mathrm{C}$.

\section{Temperature optima and stability}

Effect of temperature on purified protease activity was determined using caseinolytic assay. The enzyme was found active at temperature ranging from 50 to $70^{\circ} \mathrm{C}$ with an optimum activity at $60^{\circ} \mathrm{C}$ (Figure $3 \mathrm{~A}$ ). After $70^{\circ} \mathrm{C}$ the enzyme activity was decreased rapidly. The temperature stability profile revealed that the enzyme was active up to100 min at the temperature between 50 to $70^{\circ} \mathrm{C}$. The protease activities relative to control at 50,60 , and $70^{\circ} \mathrm{C}$ were about 80,87 and $82 \%$ respectively (Figure $3 \mathrm{~B}$ ).

\section{Effect of inhibitors and metal ions}

In order to determine the nature of the purified protease, the effect of various inhibitors (PMSF, EDTA, DTNB and $\beta$-mercaptoethanol) on enzyme activity was investigated. The enzyme activity was completely inhibited by the serine protease inhibitor PMSF, which indicated that the purified enzyme belongs to serine-type protease family (Figure 4). The thiol reagent DTNB had no influence on the protease activity, while the enzyme activity was slightly inhibited by the chelating agent EDTA and $\beta$-mercaptoethanol. The effect of various metal ions (at three different concentrations; 1,5 and $10 \mathrm{mM}$ ) on the activity of purified protease was investigated. Results are summarized in Table 2. Enzyme retained $90 \%$ of its activity in presence of $\mathrm{Ca}^{2+}, \mathrm{Zn}^{2+}, \mathrm{Ba}^{2+}$, $\mathrm{Hg}^{2+}, \mathrm{Cu}^{2+}, \mathrm{Na}^{+}$, and $\mathrm{K}^{+}$at the concentration $5 \mathrm{mM}$ of each metal ion. However, more inhibition in enzyme activity was recorded with each above-mentioned metal ion at the concentration of $10 \mathrm{mM}$ while about $20 \%$ enzyme activity was inhibited at $15 \mathrm{mM}$ concentration.

\section{Effect of surfactants and oxidizing agents}

The effect of anionic surfactant (SDS), nonionic surfactants (Tween-20, Tween-80, Triton X-100) and oxidizing agents $\left(\mathrm{H}_{2} \mathrm{O}_{2}\right.$, and bleach) on purified P. americana protease activity was investigated and the results are summarized in Table 3. Three different concentrations (1,5 and $10 \%)$ of all above-mentioned reagents were tested against purified protease activity. Enzyme showed 93, 63, and 95\% activity in presence of $1 \%$ Tween-20, Tween- 80 and Triton X-100, respectively, while $60 \%$ enzyme activity was found to be retained in presence of these three nonionic surfactants at the concentration of 5 and $10 \%$. Similarly, enzyme was able to retain $60 \%$ activity in the presence of $10 \%$ SDS. As shown in Table 3, nearly $14 \%$ enzyme activity was inhibited by $\mathrm{H}_{2} \mathrm{O}_{2}$ at the concentration of $1 \%$. However, at 5 and $10 \%$ concentration $\mathrm{H}_{2} \mathrm{O}_{2}$ inhibited around 37 and $36 \%$ protease activity, respectively. Enzyme retained $80 \%$ of its activity in presence of $1 \%$ bleach, whereas 34 and $40 \%$ enzyme activity was inhibited by bleach at 5 and $10 \%$ concentration, respectively.

Table 1 Purification of $\boldsymbol{P}$. americana protease

\begin{tabular}{lllllllc}
\hline $\begin{array}{l}\text { Purification } \\
\text { Step }\end{array}$ & Volume $(\mathrm{mL})$ & $\begin{array}{l}\text { Activity } \\
(\mu \mathrm{M} / \mathbf{m L} / \mathbf{m i n})\end{array}$ & $\begin{array}{l}\text { Total } \\
\text { activity }(\mu \mathrm{M})\end{array}$ & $\begin{array}{l}\text { Specific activity } \\
(\mu \mathrm{M} / \mathbf{m g} / \mathbf{m i n})\end{array}$ & $\begin{array}{l}\text { Total } \\
\text { protein }(\mathbf{m g})\end{array}$ & $\begin{array}{l}\text { Purification } \\
\text { fold }\end{array}$ & $\begin{array}{l}\text { Purification } \\
\text { yield } \%\end{array}$ \\
\hline Crude & 50 & 4.117 & 164.68 & 1.52 & 250 & 1 & 100 \\
Acetone ppt & 6 & 1.116 & 6.669 & 2.2 & 30 & 1.4 & 4 \\
Gel filtration & 5 & 6.5 & 32.5 & 6.5 & 25 & 4.2 & 19 \\
\hline
\end{tabular}

Purification fold, percentage yield and activity of each purification step. 


Figure $\mathbf{1}$ Purification and molecular mass determination of $P$. americana protease (A). The purified enzyme was separated on 12\% SDS-PAGE
and protein bands were stained with CBBR-250. Lane 1, standard molecular weight markers, Lane 2, crude extract, Lane 3, acetone precipitate, Lane 4,
gel filtration fraction. (B) Detection of protease activity of purified enzyme by gel X-ray film contact print method. Fractions from each purification step
were resolved on 10\% native-PAGE and protease activity isoforms were visualized on X-ray film. Lane 1, crude extract, Lane 2, acetone precipitate, Lane
3, gel filtration fraction.
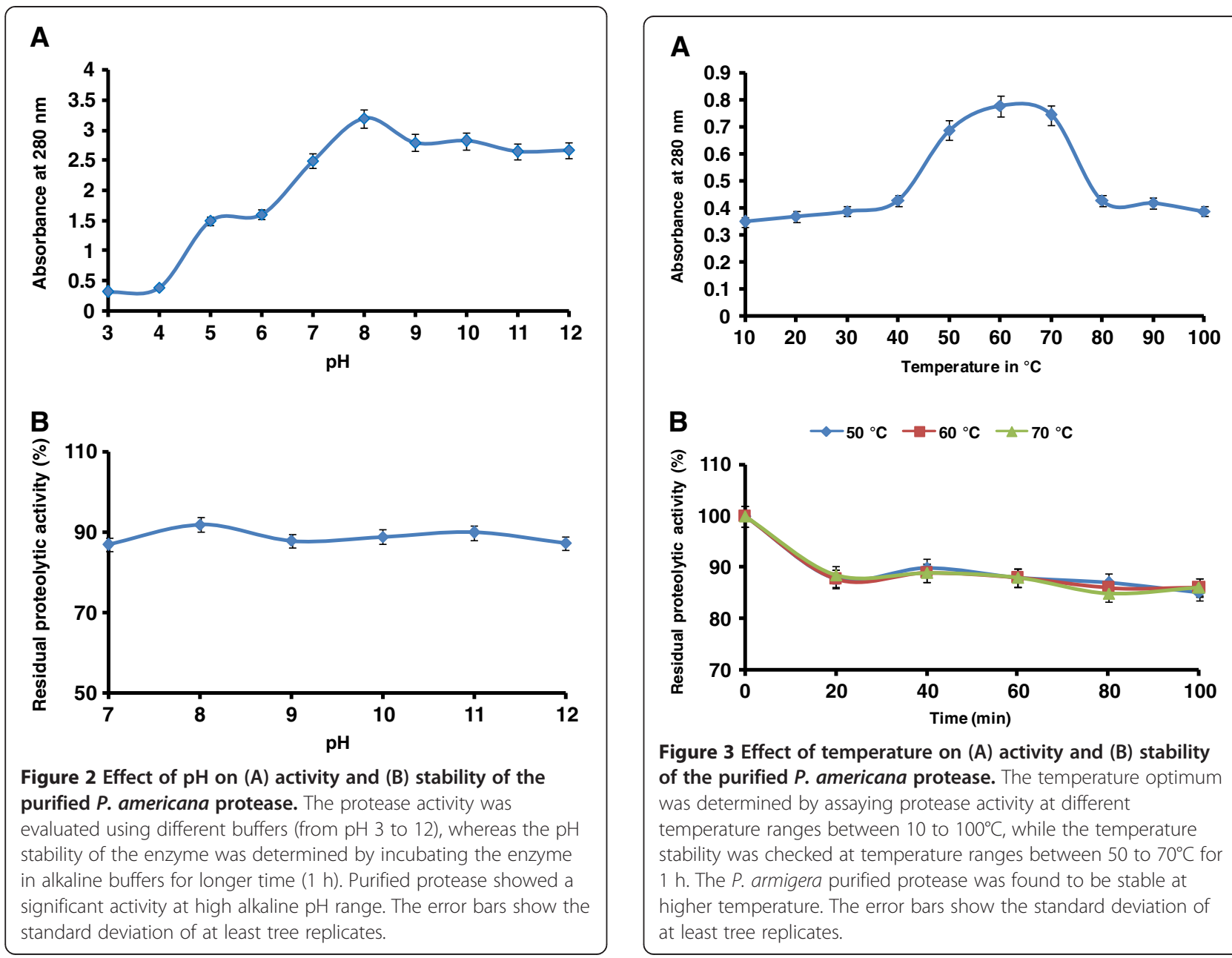

Figure 3 Effect of temperature on (A) activity and (B) stability of the purified $P$. americana protease. The temperature optimum was determined by assaying protease activity at different temperature ranges between 10 to $100^{\circ} \mathrm{C}$, while the temperature stability was checked at temperature ranges between 50 to $70^{\circ} \mathrm{C}$ for $1 \mathrm{~h}$. The $P$. armigera purified protease was found to be stable at higher temperature. The error bars show the standard deviation of at least tree replicates. 


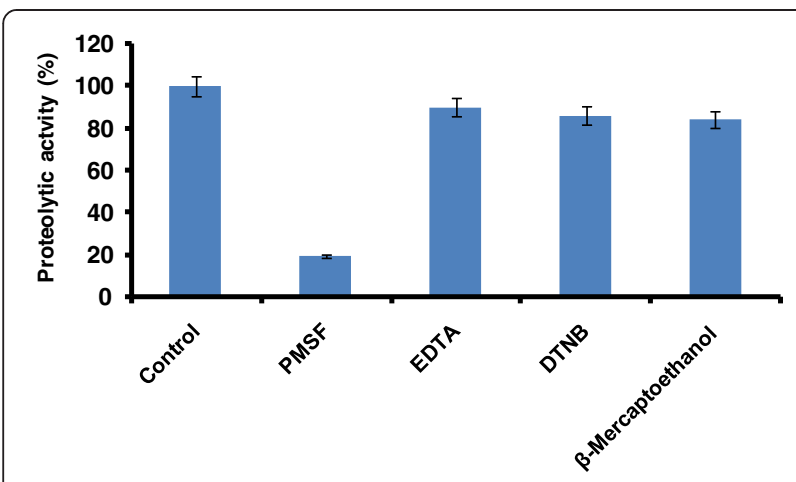

Figure 4 Effect of inhibitors on the activity of purified $P$. americana protease. Different inhibitors were pre-incubated with the purified enzyme for 30 min at $40^{\circ} \mathrm{C}$ and assay was carried out using casein as substrate. The activity of enzyme without inhibitor was considered as $100 \%$. The error bars show the standard deviation of at least tree replicates.

Effect of organic solvents on protease activity

The influence of various organic solvents on the activity of purified protease was studied and obtained result showed that the protease activity was increased up to 5 to $10 \%$ in presence of acetone, butanol, and hexane. Around 15\% protease activity was inhibited by propanol, DMSO and toluene while enzyme retained its $100 \%$ activity in presence of xylene, benzene and ethanol (Figure 5A).

\section{Stability of protease toward commercial detergents}

Effect of various commercial detergents on protease activity was studied at three different concentrations viz. 1, 10 and $100 \mathrm{mg} / \mathrm{mL}$. The enzyme retained its $90 \%$ activity in presence of Tide, Wheel, Surf and Rin, whereas enzyme showed $80 \%$ activity in presence of Ariel and Henko. Similar results were observed at each tested concentration of detergents (Figure 5B).

\section{Discussion}

Proteases with strong activity and stability in highly alkaline $\mathrm{pH}$ range are essentially important for biotechnological

Table 2 Effect of metal ions on the activity of purified $P$. americana protease

\begin{tabular}{llll}
\hline Metal ion & \multicolumn{3}{c}{ Relative activity (\%) } \\
\cline { 2 - 4 } & $\mathbf{5} \mathbf{~ \mathbf { M }}$ & $\mathbf{1 0} \mathbf{~} \mathbf{M}$ & $\mathbf{1 5} \mathbf{~ m M}$ \\
\hline Control & 100 & 100 & 100 \\
$\mathrm{Ca}^{2+}$ & 95 & 94 & 80 \\
$\mathrm{Zn}^{2+}$ & 95 & 84 & 80 \\
$\mathrm{Cu}^{2+}$ & 95 & 75 & 80 \\
$\mathrm{Ba}^{2+}$ & 94 & 93 & 82 \\
$\mathrm{Hg}^{2+}$ & 97 & 90 & 80 \\
$\mathrm{Na}^{2+}$ & 92 & 82 & 83 \\
$\mathrm{~K}^{+}$ & 92 & 84 & 85 \\
\hline
\end{tabular}

Table 3 Stability of purified $P$. americana protease in the presence of various surfactants and oxidizing agents

\begin{tabular}{llll}
\hline Surfactant/oxidizing & \multicolumn{3}{c}{ Relative activity (\%) } \\
\cline { 2 - 4 } agent & $\mathbf{1 \%}$ & $\mathbf{5 \%}$ & $\mathbf{1 0 \%}$ \\
\hline Control & 100 & 100 & 100 \\
Tween-20 & 93 & 67 & 61 \\
Tween-80 & 83 & 69 & 64 \\
Triton X-100 & 95 & 81 & 77 \\
SDS & 76 & 64 & 60 \\
$\mathrm{H}_{2} \mathrm{O}_{2}$ & 86 & 63 & 64 \\
Bleach & 80 & 66 & 60 \\
\hline
\end{tabular}

applications. For example, proteases constitute one of the most important groups of enzymes, which are used as key ingredients in detergent formulation [22]. With the advent of new frontiers in biotechnology, the spectrum of protease application has expanded into many new fields such as

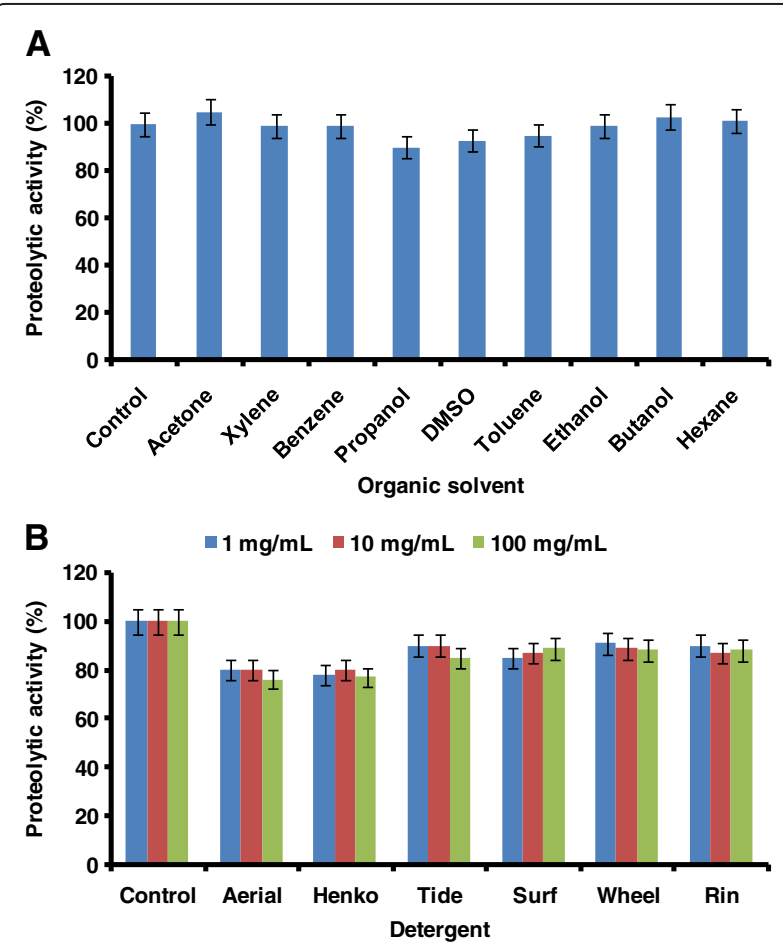

Figure 5 Effects of various organic solvents on enzyme activity (A). The effect of organic solvent was determined by incubating the purified $P$. americana protease with different organic solvent for $1 \mathrm{~h}$ and the enzyme activity was measured under standard assay conditions. The activity of the enzyme without organic solvent was taken as 100\%. The error bars show the standard deviation of at least tree replicates. (B) Stability of the purified protease from $P$. americana in the presence of various commercial detergents. The stability with commercial detergents was determined by incubating the purified enzyme with each detergent at different concentrations such as 1, 10 and $100 \mathrm{mg} / \mathrm{mL}$ for $1 \mathrm{~h}$ at $40^{\circ} \mathrm{C}$. Enzyme activity of control sample without any detergent was considered as $100 \%$. The error bars shows the standard deviation of at least tree replicates. 
clinical, pharmaceutical and analytical chemistry [23-27]. Generally alkaline proteases used in industrial processes are obtained from microorganism; however, these sources have limitations while using in industries. Thus, it is essential to search alternative and reliable sources of proteases with high activity and stability in various conditions. Insect midgut can be an important source to obtain proteases with necessary properties. Previously, we did find high protease activity in the gut of $P$. americana, therefore the present study is an attempt to isolate and characterize chemostable proteases from this important insect species [15].

The alkaline protease from $P$. americana midgut caecae was purified and characterized for its biochemical properties [28-30]. Earlier, Lopez and terra [28] purified a $29 \mathrm{kDa}$ digestive trypsin from $P$. americana and the purification of enzyme was achieved using a combination of two anionic chromatographic steps [28]. Similar protocol was used for the purification of the trypsin from Tenebrio molitor [31]. Both above-mentioned studies concluded that, although similar in many instances, $P$. americana and T. molitor trypsins differ mainly in their charges. Surprisingly, $P$. americana trypsin binds with anionic resins both at pH 5.0 and 10.0, despite its $p I$ of 6.0. Perhaps local surface charges are strong enough to make possible the binding even when the molecule overall charge would be contrary to that. From the observed molecular weight enzyme isolated by us, seems similar to those trypsins isolated from $P$. americana and T. molitor. Moreover, $P$. americana protease isolated in the present study, perhaps the known trypsin reported by Lopez and terra [28].

The purified protease was found to be active at alkaline $\mathrm{pH}(>8)$. The enzyme also showed good stability in broad $\mathrm{pH}$ range i.e. from $\mathrm{pH} 7$ to 12 . It has been well known that a large number of proteases present in the insect gut act in high alkaline $\mathrm{pH}$ range. Our findings are in accordance with the properties of proteases reported from previous studies; cockroach [15,28,32], Spilosoma obliqua (pH 11.0) [33], Spodoptera litura ( $\mathrm{pH} 9.0,10.5$, and 11.0) [34], Heliothis zea ( $\mathrm{pH} 11.0)$ [35], Galleria mellonella ( $\mathrm{pH} 10.5$ and 11.2) [36] Helicoverpa armigera ( $\mathrm{pH} 9.5$ and 10.0) [37], and Tenebrio molitor ( $\mathrm{pH}$ 8.5) [38]. Most of the insects have midgut $\mathrm{pH}$ in the range of 6 to 10 . Gut $\mathrm{pH}$ conditions are likely to have a major influence on the efficiency of nutrient extraction in insects. The high $\mathrm{pH}$ of many insect guts has been attributed to an adaptation of their leaf-eating ancestors for extracting hemicelluloses from plant cell walls [38]. Furthermore, there are some correlations between the midgut enzymes and surrounding symbiotic microflora. Studies from analysis of genomes have concluded that insects do not possess the entire metabolic repertoire to efficiently extract the maximum of nutrients from their food and they depend on their gut microbial community for this purpose [39]. Gut bacteria are unique in the sense that they can thrive in the hostile environment of gut, withstanding extremes of $\mathrm{pH}$ and ionic composition and steep redox gradations. Moreover, gut microorganisms are critical to the nutrition, physiology, detoxification and resistance mechanism [40]. Overall, it seems that gut microorganisms have significant contribution in multiple isoforms, diversity and stability of enzymes found in insect gut.

Optimum temperature for activity of alkaline protease was determined to evaluate its suitability for biotechnological applications. The purified alkaline protease exhibited a temperature optimum at $60^{\circ} \mathrm{C}$ and stability in the temperature range 50 to $70^{\circ} \mathrm{C}$. Previously, we reported the temperature optima for proteases in the crude caecae extract of $P$. americana was around 50 to $70^{\circ} \mathrm{C}$ [15]. The alkaline proteases from other insects also found to be thermostable and their temperature optima were between $50-60^{\circ} \mathrm{C}$ [34]. For application in detergents and tanning processes, alkaline protease(s) with high temperature and alkaline $\mathrm{pH}$ optima are desirable $[1,9]$. Thus, insect proteases can be suitable candidates for these purposes, as they exhibit required characteristics. Studies on enzyme inhibitors further insights into biochemical properties of the $P$. americana purified protease. The purified enzyme was characterized as a serine protease because its activity was completely inhibited by a specific serine protease inhibitor PMSF. PMSF binds specifically to a serine residue in the active site of serine protease. This is a result of the hyperactivity of serine residue caused by the specific environmental conditions in the enzyme's active site. Because PMSF binds covalently to the enzyme, the complex can be viewed by X-ray crystallography; it can therefore be used as a chemical label to identify an essential active site serine in an enzyme $[41,42]$. The chelating agents DTNB, EDTA and $\beta$-mercaptoethanol had no influence on the activity of purified enzyme. The high activity of $P$. americana protease in presence of chelating agent is very useful for employing as detergent additive since most of the detergents contain chelating agents as major component.

The purified protease from $P$. americana showed considerable activity at high concentration of various metal ions. Proteases having stability towards higher concentration of metal ions are usually suitable in leather processes, sewage treatment etc. In addition to the stability towards temperature, $\mathrm{pH}$, and metal ions, enzyme used in detergent formulation must be active in presence of surfactants, oxidizing agents and other detergent additive $[4,43]$. Alkaline proteases from high yielding bacterial strains have been studied extensively. However, few reports are available on the stability of the alkaline proteases towards surfactants and oxidizing agents [44]. Most commonly used proteases such as subtilisin, esperase and savinase are stable in various detergent components but unstable in oxidizing agents [44]. P. americana protease exhibited 
excellent stability and activity against surfactants and oxidizing agents. There is great industrial demand for organic solvent stable proteases to employ in the synthesis of useful pharmaceutical products [45]. Therefore, proteases, which are naturally stable in organic solvents, are essential for synthetic reactions and peptide synthesis and accordingly the protease from $P$. americana exhibited such features.

\section{Conclusion}

Present study deals with the characterization and potential applications of a serine alkaline protease purified from $P$. americana. SDS-PAGE and native gel followed zymographic analyses revealed monomeric nature of the enzyme with a molecular weight of $27.8 \mathrm{kDa}$. The purified protease was found active and stable in higher temperature and alkaline $\mathrm{pH}$ range. Enzyme exhibited excellent stability and compatibility towards detergents, oxidizing and bleaching agents. Obtained results point out that the essential properties of $P$. americana protease can be exploited in various important bioformulations and industrial applications. Altogether, insects appear to be a potential source to obtain industrially important proteases. Protein engineering has played a central role in improving commercially important enzymes and in finding new applications of proteins quite different from their natural function. In future, protein engineering will offer possibilities of generating proteases with entirely new functions. Hence, although alkaline proteases already play an important role in several industries, their potential is much greater and their applications in future processes are likely to increase in the near future.

\section{Competing interests}

The authors declare that they have no competing interests.

\section{Authors' contributions}

PTS, PRL and VKH designed the research and wrote the manuscript. PTS and PRL performed the research. APG helped in data analysis and writing of the manuscript. All authors read and approved the final manuscript.

\section{Acknowledgments}

PTS acknowledges the Golden Jubilee Fellowship from Dr Babasaheb Ambedkar Marathwada University. PRL is a recipient of Research Associateship from Department of Biotechnology (DBT), Government of India, New Delhi. Project funding under CSIR network programs in XII plan (BSC0120) to CSIR-National Chemical Laboratory is greatly acknowledged.

\section{Author details}

'Department of Biochemistry, Dr. Babasaheb Ambedkar Marathwada University, Aurangabad 431004, MS, India. ${ }^{2}$ Plant Molecular Biology Unit, Division of Biochemical Sciences, CSIR-National Chemical Laboratory, Dr. Homi Bhabha Road, Pune 411008, MS, India.

Received: 19 April 2013 Accepted: 4 November 2013

Published: 14 November 2013

\section{References}

1. Beg QK, Gupta R: Purification and characterization of an oxidation-stable, thiol-dependent serine alkaline protease from Bacillus mojavensis. Enzyme Microb Technol 2003, 3:294-304.
2. Rao MB, Tanksale AM, Ghatge MS, Deshpande W: Molecular and biotechnological aspects of microbial proteases. Microbiol Mol Biol Rev 1998, 62:597-635.

3. Bhaskar N, Sudeepa ES, Rashmi HN, Selvi AT: Partial purification and characterization of protease of Bacillus proteolyticus CFR3001 isolated from fish processing waste and its antibacterial activities. Bioresource Technol 2007, 98:2758-2764.

4. Gupta R, Beg QK, Lorenz P: Bacterial alkaline proteases: molecular approaches and industrial applications. Appl Microbiol Biotechnol 2002, 59:15-32.

5. Jellouli K, Bougatef A, Manni L, Agrebi R, Siala R, Younes I, Nasri M: Molecular and biochemical characterization of an extracellular serine-protease from Vibrio metschnikovii J1. J Ind Microbiol Biotechnol 2009, 36:939-948.

6. Sareen R, Mishra P: Purification and characterization of organic solvent stable protease from Bacillus licheniformis RSP-09-37. Appl Microbiol Biotechnol 2008, 79:399-405.

7. Najafi MF, Deobagkar D, Deobagkar D: Potential application of protease isolated from Pseudomonas aeruginosa PD100. Electron J Biotechnol 2005 8:197-203.

8. Maurer KH: Detergent protease. Curr Opin Biotechnol 2004, 15:330-334.

9. Joo HS, Kumar CG, Park GC, Paik SR, Chang CS: Oxidant and SDS-stable alkaline protease from Bacillus clausii 1-52: production and some properties. J Appl Microbiol 2003, 95:267-272.

10. Christeller JT, Laing WA, Markwick NP, Burgess EPJ: Midgut protease activities in 12 phytophagous lepidopteran larvae: dietary and protease inhibitor interactions. Insect Biochem Mol Biol 1992, 22:735-746.

11. Applebaum SW: Biochemistry of digestion. In Comprehensive Insect Physiology; Biochemistry and Pharmacology, Volume 4. Edited by Kerkot GA, Gilbert LI. New York: Pergamon; 1985:279-311.

12. Terra WR: Evolution of digestive system of insect. Annu Rev Entomol 1990, 35:181-200.

13. Terra WR: Evolution and function of insect peritrophic membrane. Ciencia Cult 1996, 48:317-324.

14. Anwar AM, Saleemuddin M: Alkaline protease from Spilosoma obliqua: potential applications in bio-formulations. Biotechnol Appl Biochem 2000 31:85-89.

15. Hivrale VK, Chougule NP, Chhabda PJ, Giri AP, Kachole MS: Unraveling biochemical properties of cockroach (Periplaneta americana) proteinases with a gel X-ray film contact print method. Comp Biochem Physiol B 2005, 141:261-266.

16. Lowry OH, Rosebrough NJ, Farr AL, Randall JR: Protein measurement with the Folin phenol reagent. J Biol Chem 1951, 193:265-275.

17. Lomate PR, Sanatan PT, Kalve ND, Hivrale VK: Characterization and applicability of digestive proteinases from hepatopancreas of Barytelphusa cunicularis. Food Biotechnol 2011, 25:1-15.

18. Hivrale VK, Lomate PR, Kalve ND, Kachole MS: Periplaneta americana midgut proteases differentially expressed against dietary components from different plant seeds. Physiol Entomol 2011, 36:180-186.

19. Laemmli UK: Cleavage of structural proteins during the assembly of the head of bacteriophage T4. Nature 1970, 227:680-685.

20. Lomate PR, Hivrale VK: Wound and methyl jasmonate induced pigeon pea defensive proteinase inhibitor has potency to inhibit insect digestive proteinases. Plant Physiol Biochem 2012, 57:193-199.

21. Lomate PR, Hivrale VK: Induction of leucine aminopeptidase (LAP) like activity with wounding and methyl jasmonate in pigeonpea (Cajanas cajan) suggests the role of these enzymes in plant defense in leguminosae. Plant Physiol Biochem 2011, 49:609-616.

22. Layman PL: Industrial enzymes: battling to remain specialties. Chem Eng News 1986, 64:11-14.

23. Joo HS, Chang CS: Oxidant and SDS stable alkaline protease from a halotolerant Bacillus clausii I-52: enhanced production and simple purification. J Appl Microb 2005, 98:491-497.

24. Joo HS, Kumar CG, Park SR, Chang CS: Bleach resistance alkaline protease produced by a Bacillus species isolated from the Korean Polychaete Perriserrula leucophryna. Process Biochem 2004, 39:1441-1447.

25. Kulakova LA, Khurihara GT, Yoshimura T, Esaki N: Cold active serine protease from the psychrotrophic bacterium Shewanella strainsc 10: gene clining and enzyme purification and characterization. Appl Environ Microbiol 1999, 65:611-617.

26. Samal BB, Karan B, Stabinsk Y: Stability of two novel serine proteinases in commercial laundry detergent formulations. Biotechnol Bioeng 1990, 35:650-652. 
27. Anwar AM, Saleemuddin M: Alkaline $\mathrm{pH}$ acting digestive enzymes of the polyphagous insect pest Spilosoma obliqua: stability and potential as detergent additives. Biotechnol Appl Biochem 1997, 25:43-46.

28. Loops AR, Terra WR: Purification, properties and substrate specificity of a digestive trypsin from Periplaneta americana (Dictyoptera). Insect Biochem Mol Biol 2003, 33:407-415.

29. Ock MS, Kim BJ, Kim SM, Byun KH: Cloning and expression of trypsinencoding cDNA from Blattella germanica and its possibility as an allergen. Korean J Parasitol 2005, 43:301-310.

30. Sudha VT, Arora N, Gaur SN, Pasha S, Singh BP: Identification of a serine protease as a major allergen (Per a 10) of Periplaneta americana. Allergy 2008, 63:768-776.

31. Cristofoletti PT, Ribeiro AF, Terra WR: Apocrine secretion of amylase and exocytosis of trypsin along the midgut of Tenebrio molitor larvae. J Insect Physiol 2001, 47:143-155.

32. Konstantin V, Yuliya T, Natraj K, Frantisek S: Proteinase, amylase, and proteinase-inhibitor activities in the gut of six cockroach species. J Insect Physiol 2007, 53:794-802.

33. Anwar A, Saleemuddin M: Purification and characterization of a digestive alkaline protease from the larvae of Spilosoma oblique. Arch Insect Biochem Physiol 2002, 51:1-12.

34. Ahmad Z, Saleemuddin M, Siddiqui M: Purification and characterization of three alkaline proteases from the larva of army worm Spodoptera litura. Insect Biochem 1980, 10:667-673.

35. Kloke JA, Chan BG: Effects of cotton condensed tannin on feeding and digestion in the cotton pest Heliothis zea. J Insect Physiol 1982, 28:911-915.

36. Hamed MB, Attias J: Isolation and partial characterization of two alkaline proteases of greater wax moth Galleria mellonella L. Insect Biochem 1987, 17:653-658

37. Johnston KA, Lee MJ, Gatehouse JA, Anstee JH: The partial purification and characterization of serine protease activity in the midgut of larval Helicoverpa armigera. Insect Biochem 1991, 21:389-397.

38. Tsybina TA, Dunaevsky YE, Belozersky MA, Zhuzhikov DP, Oppert B, Elpidina EN: Digestive proteinases of yellow mealworm (Tenebrio molitor) larvae: purification and characterization of a trypsin-like proteinase. Biochem Mosc 2005, 70:300-305.

39. Appel HM: The chewing herbivore gut lumen: physicochemical conditions and their impact on plant nutrients, allelochemicals and insect pathogens. In Insect-Plant Interactions, vol. Edited by Bernays EA. Boca Raton, FL: V. CRC Press; 1994:209-223.

40. Engel $P$, Moran NA: The gut microbiota of insects-diversity in structure and function. FEMS Microbiol Rev 2013, 37:699-735.

41. James GT: Inactivation of the protease inhibitor phenylmethyldulfonyl fluoride in buffers. Analytical Biochem 1978, 86:574-579.

42. Fahrney DE, Grold AM: Specific trypsin and chymotrypsin inhibitor. J Am Chem Soc 1963, 85:997.

43. Kumar CG, Tiwari MP, Jany KD: Microbial alkaline proteases from a bioindustrial view point. Biotechnol Adv 1999, 17:561-594.

44. Hadar A, Bougatef A, Agrebi R, Sellami-Kamoun A, Nasri M: A novel surfactant-stable alkaline serine-protease from a newly isolated Bacillus mojavensis A21: purification and characterization. Process Biochem 2009, 44:29-35.

45. Gupta R, Gupta K, Khan S: Bleach-stable alkaline protease from Bacillus sp. Biotechnol Lett 1999, 21:135-138.

doi:10.1186/1471-2091-14-32

Cite this article as: Sanatan et al: Characterization of a chemostable serine alkaline protease from Periplaneta americana. BMC Biochemistry 2013 14:32.

\section{Submit your next manuscript to BioMed Central and take full advantage of:}

- Convenient online submission

- Thorough peer review

- No space constraints or color figure charges

- Immediate publication on acceptance

- Inclusion in PubMed, CAS, Scopus and Google Scholar

- Research which is freely available for redistribution

Submit your manuscript at www.biomedcentral.com/submit 